\title{
Maximising Yield and Engine Efficiency Using Optimised Waste Cooking Oil Biodiesel
}

\author{
Luqman Razzaq ${ }^{1}$, Shahid Imran ${ }^{1}$, Zahid Anwar ${ }^{1}$, Muhammad Farooq ${ }^{1}$,

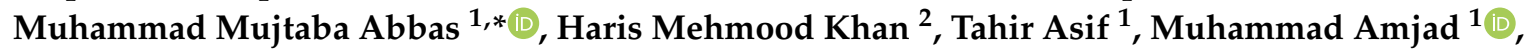 \\ Manzoore Elahi M. Soudagar ${ }^{3}$ (D), Nabeel Shaukat ${ }^{2}$ (D) I. M. Rizwanul Fattah ${ }^{4, *(D)}$ \\ and S. M. Ashrafur Rahman 5,*(D)
}

1 Department of Mechanical, Mechatronics and Manufacturing Engineering, New Campus, University of Engineering and Technology, Lahore 54890, Pakistan; luqmanrazzaq@uet.edu.pk (L.R.); s.imran@uet.edu.pk (S.I.); zahidanwar@uet.edu.pk (Z.A.); engr.farooq@uet.edu.pk (M.F.); tahir.asif@uet.edu.pk (T.A.); amjad9002@uet.edu.pk (M.A.)

2 Department of Chemical, Polymer and Composite Materials Engineering, New Campus, University of Engineering and Technology, Lahore 54890, Pakistan; hariskhan@uet.edu.pk (H.M.K.); 2015ch284@student.uet.edu.pk (N.S.)

3 Department of Mechanical Engineering, Faculty of Engineering, University of Malaya, Kuala Lumpur 50603, Malaysia; me.soudagar@gmail.com

4 School of Information, Systems and Modelling, Faculty of Engineering and IT, University of Technology Sydney, Sydney, NSW 2007, Australia

5 Biofuel Engine Research Facility, Queensland University of Technology, Brisbane City, QLD 4000, Australia

* Correspondence: m.mujtaba@uet.edu.pk (M.M.A.); rizwanul.buet@gmail.com (I.M.R.F.); s2.rahman@qut.edu.au (S.M.A.R.)

Received: 6 October 2020; Accepted: 11 November 2020; Published: 13 November 2020

check for updates

\begin{abstract}
In this study, waste cooking oil (WCO) was used as a feedstock for biodiesel production, where the pretreatment of WCO was performed using mineral acids to reduce the acid value. The response surface methodology (RSM) was used to create an interaction for different operating parameters that affect biodiesel yield. The optimised biodiesel yield was $93 \%$ at a reaction temperature of $57.50{ }^{\circ} \mathrm{C}$, catalyst concentration $0.25 \mathrm{w} / \mathrm{w}$, methanol to oil ratio 8.50:1, reaction stirring speed $600 \mathrm{rpm}$, and a reaction time of $3 \mathrm{~h}$. Physicochemical properties, including lower heating value, density, viscosity, cloud point, and flash point of biodiesel blends, were determined using American Society for Testing and Materials (ASTM) standards. Biodiesel blends B10, B20, B30, B40, and B50 were tested on a compression ignition engine. Engine performance parameters, including brake torque (BT), brake power (BP), brake thermal efficiency (BTE), and brake specific fuel consumption (BSFC) were determined using biodiesel blends and compared to that of high-speed diesel. The average BT reduction for biodiesel blends compared to HSD at $3000 \mathrm{rpm}$ were found to be $1.45 \%, 2 \%, 2.2 \%, 3.09 \%$, and 3.5\% for B10, B20, B30, B40, and B50, respectively. The average increase in BSFC for biodiesel blends compared to HSD at $3500 \mathrm{rpm}$ were found to be $1.61 \%, 5.73 \%, 8.8 \%, 12.76 \%$, and 18\% for B10, B20, B30, B40, and B50, respectively.
\end{abstract}

Keywords: biodiesel; waste cooking oil; transesterification; response surface methodology; central composite design

\section{Introduction}

Over the last few decades, the rapid decline of fossil fuels has become a significant problem. On the other hand, the energy demand is continuously rising owing to the rapidly expanding population coupled with the increased rate of urbanisation [1-3]. This scenario demands the adoption 
of alternative energy resources to address the issues related to the energy as well as the environment [4-7]. Recently, biofuels produced from a variety of naturally occurring resources $[8,9]$ have emerged as an alternative energy source owing to their comparable physicochemical, performance, and emission characteristics [10-12]. The main hindrance in the commercialisation of biodiesel is its production cost, and the production cost mainly depends upon the feedstock oil used. The use of edible oils for the production of biodiesel may cause an imbalance in the food chain, and has sparked the 'food vs. fuel' debate for decades. Waste cooking oil (WCO) can be a potential alternative to edible oil for biodiesel production. WCO, when disposed of without treatment, causes environmental pollution. The use of WCO for biodiesel production not only reduces the production cost of biodiesel, but also decreases the environmental burden.

Generally, biodiesel can be used as a blend (with or without additives) with diesel in diesel engines without any modification in the engines [13,14]. Biodiesel can be converted to fatty acid esters by reacting fatty acids and short-chain alcohol through a process known as transesterification $[15,16]$. Homogeneous alkaline catalysts such as $\mathrm{KOH}, \mathrm{NaOH}$, and $\mathrm{CH}_{3} \mathrm{ONa}$ have been used as catalysts in this process $[17,18]$. Methanol is suitable for the transesterification process [19]. The biodiesel yield depends upon the operating parameters of the transesterification process, which include temperature, catalyst concentration, methanol to oil ratio, reaction speed, and reaction time [20]. The operating parameters should be optimised to obtain the optimum yield of fatty acid methyl ester (FAME) [21]. The effectiveness of the transesterification process is assessed by the reaction kinetics, mass transfer, and equilibrium in the reaction mixture. The results of this process are used to predict the conversion yield and design a model which can be used for the prediction of conversion yield [22].

Performance of CI engines operated with biodiesel depends upon different factors including, but not limited to, compression ratio, injection timing and injection pressure [23,24]. A slight reduction in brake thermal power and brake torque was observed when biodiesel tested on the six cylinder DI diesel engine [25]. Biodiesel blends significantly reduced emissions such as carbon monoxide, carbon dioxide with a slight increase in oxides of nitrogen NOx [26,27]. A previous study by Nirmala et al. [28] tested pure WCO based biodiesel (WCOBD) and compared the results with that of pure diesel. WCOBD showed 4.2\% higher BSFC, 3.6\% lower BTE, and 10.8\% lower BP than conventional diesel. Akcay et al. [29] studied hydrogen addition to intake air in conjunction with $25 \%$ WCO biodiesel blend (B25). The effects of hydrogen on the BSFC of B25 fuel were not significant compared to diesel fuel. Can [30] studied the engine performance of 5\% and 10\% blend of WCO with diesel and reported a slight increase in BSFC (up to $4 \%$ ) and a small reduction of BTE (up to 2.8\%) with the addition of the biodiesel for all tested engine loads.

Many techniques have been reported to optimise biodiesel yield. RSM is one of the most widely employed techniques [31-34]. RSM is a mathematical technique used for empirical model building. Yield is known as the response which depends upon independent variables which are the operating parameters of the transesterification process. RSM develops a suitable experimental design model to provide optimum operating conditions [35]. Jamshaid et al. [36] used the RSM technique for the optimisation of biodiesel yield from cottonseed oil and reported an optimum biodiesel yield of 98.3\%. Mostafaei et al. [32] examined the effect on the biodiesel yield of the independent variables reactor diameter, ultrasound strength, and liquid height. The RSM technique was used to develop interaction among these independent variables. Anwar et al. [37] investigated the yield optimisation of second-generation biodiesel produced from Australian native stone fruit oil using the RSM technique, and thereby an optimum yield of $95.8 \%$ was obtained. This article focuses on optimising the biodiesel production process from WCO of Pakistani origin using the RSM technique that involved CCD [38].

The prevalent energy crisis has adversely affected the global economy. The economies of many developing countries, like Pakistan, have gone uncompetitive due to the shortage of usable energy. With large agriculture land and a population of over two hundred and twenty million, Pakistan is one of those economies which has the potential to generate large quantities of renewable power. Besides, waste recovery after the use of edible oils is almost non-existent in such economies. This makes the 
problem more complicated. If properly treated, $\mathrm{WCO}$ has the potential to partially substitute some of the non-renewable fuels used for energy generation in the transportation, domestic, or industrial sectors. This present study is one such effort that investigates the possibility of using WCO in a diesel engine.

\section{Materials and Methods}

\subsection{Materials}

Work reported in this study is based on WCO collected from four different restaurants. Any suspended particles in WCO were first removed using filter papers of size $12.5 \mathrm{~mm}$ diameter. The filtered WCO was heated at $100{ }^{\circ} \mathrm{C}$ for $1 \mathrm{~h}$ to remove the moisture content, followed by the cooling process. HSD for preparing biodiesel blends was purchased from local market. Methanol, ethanol, sulphuric acid, potassium hydroxide, and phenolphthalein were purchased from Sigma Aldrich (purity $>99 \%$ ).

\subsection{Biodiesel Production Using WCO}

The physicochemical properties of WCO were illustrated in Table 1. Density and viscosity of WCO were observed higher than original canola oil (the source oil) due to the formation of unsaturated bonds through continuous use. This may also result in a high acid value of WCO. The acid value (AV) should be decreased before the conversion of WCO into biodiesel using mineral acids. Therefore, the raw WCO was treated with mineral acids $\left(\mathrm{H}_{2} \mathrm{SO}_{4}, \mathrm{HCl}\right.$, and $\left.\mathrm{H}_{3} \mathrm{PO}_{4}\right)$ through a process known as esterification for reducing its free fatty acid (FFA) contents, which in turn dictates the AV $[39,40]$.

Table 1. Physicochemical properties of WCO.

\begin{tabular}{ccc}
\hline Properties & Units & Values \\
\hline Density at $15{ }^{\circ} \mathrm{C}$ & $\mathrm{kg} / \mathrm{m}^{3}$ & 910.30 \\
Acid Value & $\mathrm{mg} \mathrm{KOH} / \mathrm{g}$ & 7.80 \\
Free fatty acid & $\%$ & 3.90 \\
Molecular weight & $\mathrm{g} / \mathrm{mol}$ & 860.56 \\
Viscosity at $40^{\circ} \mathrm{C}$ & $\mathrm{mm}^{2} / \mathrm{s}$ & 6.80 \\
\hline
\end{tabular}

The most important factor in the esterification process was the quantity of methanol. Increasing the methanol concentration in the mix would result in more effective FFA reduction. Other parameters were, reaction speed that was $600 \mathrm{rpm}$, the temperature was $60^{\circ} \mathrm{C}$ and time for this reaction was $3 \mathrm{~h}$. In this process amount of methanol used was $2.25 \times$ FFA and the amount of sulphuric acid used was $0.05 \times$ FFA. In this study, the maximum reduction $(74.7 \%)$ in FFA was observed by treating WCO with $\mathrm{H}_{2} \mathrm{SO}_{4}$, which was followed by $\mathrm{H}_{3} \mathrm{PO}_{4}(63.1 \%)$ and $\mathrm{HCl}(54.9 \%)$.To reduce the FFA of the WCO, the oil was treated into two steps using $\mathrm{H}_{2} \mathrm{SO}_{4}$. In the first step, $\mathrm{AV}$ was reduced from 3.9 to $1.45 \mathrm{mg} \mathrm{KOH} / \mathrm{g}$ and in the second step it was reduced to $0.34 \mathrm{mg} \mathrm{KOH} / \mathrm{g}$. After this WCO was converted into biodiesel through transesterification process. The amount of catalyst used for transesterification was determined using Equation (1)

$$
\text { Catalyst amount }=\frac{\text { Catalyst concentration } \times \text { Amount of WCO used }}{100}
$$

In the presence of $\mathrm{KOH}$ catalyst and methanol, WCO has been converted into biodiesel by transesterification process [16,40]. In general, methanol is soluble in FAME or biodiesel but insoluble in triglycerides [41]. Methanol was added to $\mathrm{WCO}$ in the presence of $\mathrm{KOH}$ at the temperature range from $\left(50\right.$ to $65^{\circ} \mathrm{C}$ ) with reaction times of $1-3 \mathrm{~h}$ which settled down overnight. Biodiesel appeared to be collected in the top layer whereas glycerine settled down in the bottom, the later was separated with a separating funnel. Transesterified biodiesel was washed with hot water continuously for removal of 
impurities which included catalysts and unused methanol. Biodiesel was washed using distilled water, and this process was done until the used distilled water became transparent. After this, the rotary evaporator was used to remove the remains of water content and methanol form biodiesel. After rotary evaporation, biodiesel was filtered with Whatman filter paper to remove the traces amount of $\mathrm{KOH}$ catalyst. Biodiesel yield was calculated using Equation (2)

$$
\text { Yield }=\frac{\text { Amount of biodiesel produced }}{\text { amount of WCO used }} \times 100
$$

\subsection{Biodiesel Property Analysis}

The lower heating value (LHV) of biodiesel was determined using a bomb calorimeter. The flashpoint and fire point of biodiesel was measured using the Cleveland open cup apparatus (Koehler, New York, NY, USA). The FAME composition was determined using GCMS 5975C with triple I Detector. Helium gas was used as a carrier gas. For determination of the acid value of WCO, $0.5 \mathrm{~N} \mathrm{KOH}$ was mixed with $50 \mathrm{~mL}$ distilled water and the mixture was used for titration. A mixture of $0.25 \mathrm{~g}$ phenathpelin and $25 \mathrm{~mL}$ ethyl alcohol was used as an indicator. A solution of $50 \mathrm{~mL}(95 \%$ ethyl alcohol and 5\% distilled water) was prepared, and a $1 \mathrm{ml}$ indicator was added into a solution of WCO. The AV of WCO was calculated using Equation (3) [40,42]

$$
\text { Acid Value }=\frac{56.1 \times \mathrm{N} \times \mathrm{V}}{\mathrm{W}}
$$

where $\mathrm{N}$ is the normality of $\mathrm{KOH}, \mathrm{V}$ is the volume of $\mathrm{KOH}$ and distilled water used for titration, and $\mathrm{W}$ is the weight of WCO used.

\subsection{Method for Biodiesel Yield Optimisation}

Five major operating parameters that affect biodiesel yield are temperature, catalyst concentration, and methanol to oil ratio, reaction speed and time. Design-Expert software 8.0.6 was used to design experimental conditions for the optimisation of biodiesel yield. The six-level, five factors CCD has been used in this study that requires 46 experiments. The ranges of operating parameters have been shown in Table 2.

Table 2. Ranges of operating parameters.

\begin{tabular}{ccc}
\hline Operating Parameters & Unit & Ranges \\
\hline Temperature & ${ }^{\circ} \mathrm{C}$ & $50-65$ \\
Catalyst Concentration & $w / w$ & $0.25-1.75$ \\
Reaction Time & $\mathrm{h}$ & $1-3$ \\
Reaction Speed & $\mathrm{rpm}$ & $400-800$ \\
Methanol to oil ratio & - & $5: 1-12: 1$ \\
\hline
\end{tabular}

The data collected from performed experiments were analysed on Design-Expert 8.0.6 (Stat-Ease, Minnesota, MN, USA) and then interpreted. Three main analytical steps required to develop optimum conditions include regression analysis, plotting of response surface and analysis of variance (ANOVA). After optimising the yield, biodiesel was produced at a pilot scale using the optimised parameters for the engine performance test. Biodiesel blends were formulated using an electrical homogeniser. This homogeniser was rotated at $1500 \mathrm{rpm}$ for $20 \mathrm{~min}$ to mix HSD with biodiesel in different concentrations. B10, B20, B30, B40, and B50 were prepared on volume bases where the concentration of biodiesel is specified with digits in blend name. 


\subsection{Engine Setup}

Blends of biodiesel obtained from WCO with diesel (B10, B20, B30, B40, and B50) was used to run the $\mathrm{CI}$ engine. The pictorial view, as well as the schematic diagram of the diesel engine test rig, is exhibited in Figure 1. The experimental setup consists of a six-cylinder, four-stroke, water-cooled, indirect injection diesel engine connected with a hydraulic dynamometer. The characteristics of the CI engine were shown in Table 3. Before collecting data, in every test, steady-state engine operation was ensured by running the engine for $20 \mathrm{~min}$. Initially, the engine was operated with pure diesel to collect baseline/reference data and later on performance with biodiesel blends was tested. Engine performance (brake torque, brake power, BTE, and BSFC) at different engine speeds (1000-3500 rpm) at full load conditions were tested and reported in the following sections.

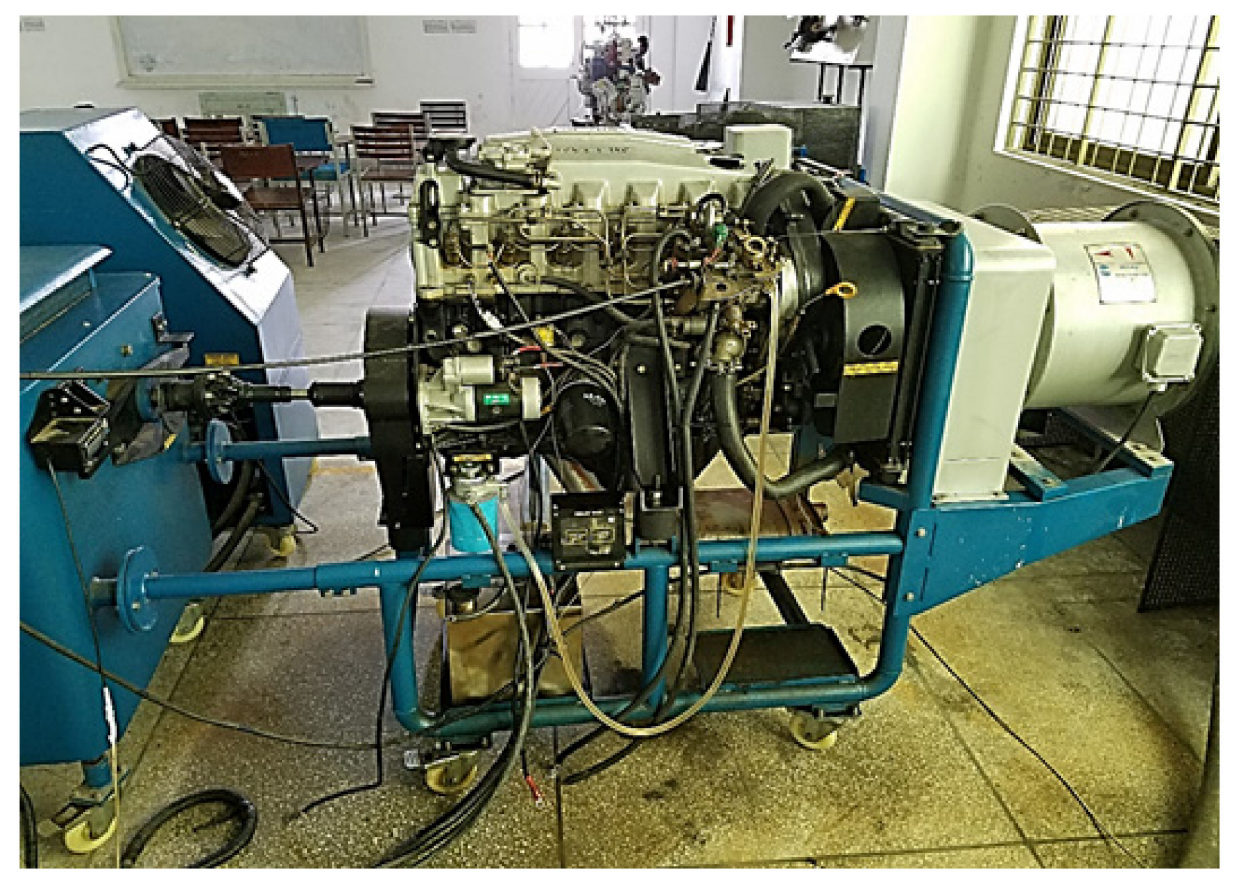

(a)

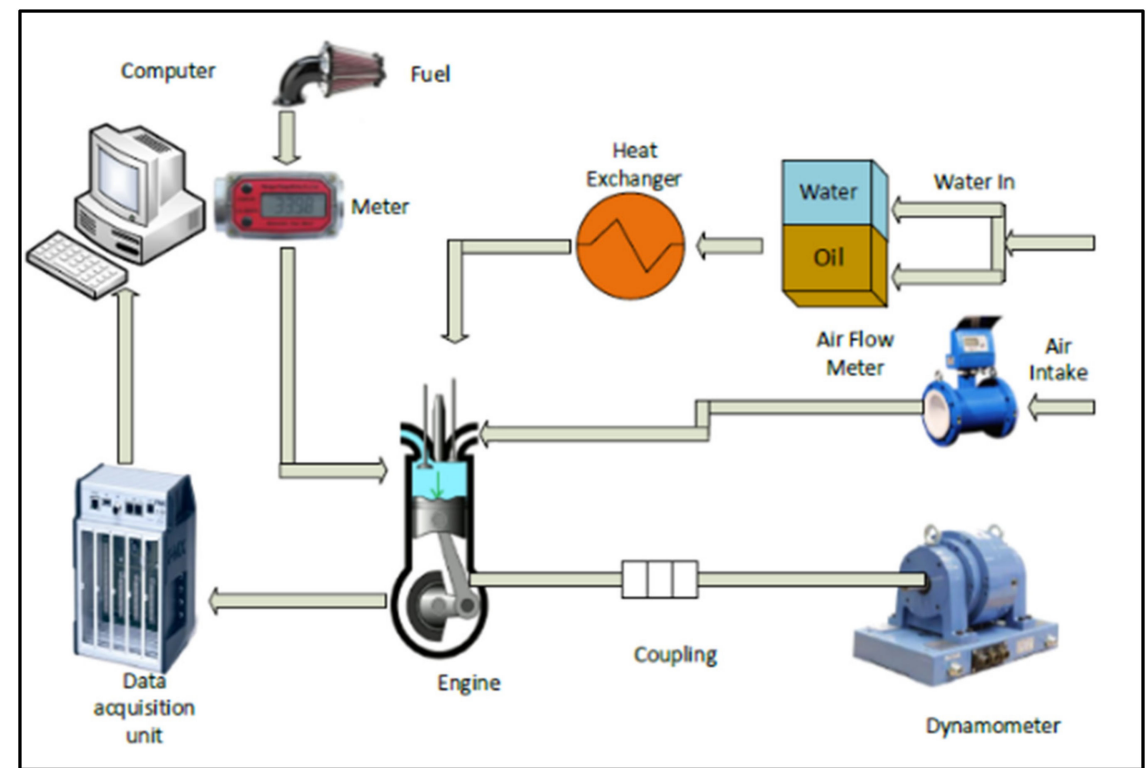

(b)

Figure 1. (a) Pictorial view and (b) schematic of the experimental testbed. 
Table 3. Specification of CI engine.

\begin{tabular}{cc}
\hline Description & Specifications \\
\hline No. of cylinders & 6 \\
Displacement $\left(\mathrm{cm}^{3}\right)$ & 2825 \\
Bore $(\mathrm{mm})$ & 85 \\
Stroke $(\mathrm{mm})$ & 83 \\
Cooling system & Water-cooled \\
Compression ratio & $22: 4$ \\
Maximum power & $73.55 \mathrm{~kW} / 4800 \mathrm{rpm}$ \\
Maximum torque & $178.48 \mathrm{Nm} / 3000 \mathrm{rpm}$ \\
Dynamometer & Hydraulic \\
Injection system & Indirect \\
\hline
\end{tabular}

\section{Results and Analysis}

\subsection{Physicochemical Properties of Biodiesel}

Table 4 presents the physicochemical properties of biodiesel sourced from the WCO. These properties have been compared with standard thermos physical properties of biodiesel as per ASTM standards. GCMS has determined the components of FAME, Table 5 illustrates the percentage composition of different long carbon chain elements.

Table 4. Physicochemical characteristics of biodiesel blends and HSD.

\begin{tabular}{cccccccc}
\hline Properties & Diesel & B100 & B10 & B20 & B30 & B40 & B50 \\
\hline Density at $15{ }^{\circ} \mathrm{C}\left(\mathrm{kg} / \mathrm{m}^{3}\right)$ & 831 & 892 & 833.5 & 837.5 & 842.5 & 851.5 & 859.5 \\
Viscosity at $40{ }^{\circ} \mathrm{C}\left(\mathrm{mm}^{2} / \mathrm{s}\right)$ & 3.9016 & 5.69 & 3.993 & 3.58 & 4.163 & 4.648 & 4.933 \\
Acid value $(\mathrm{mg} \mathrm{KOH} / \mathrm{g})$ & $<0.247$ & 0.6732 & 0.25 & 0.265 & 0.269 & 0.276 & 0.285 \\
Flashpoint $\left({ }^{\circ} \mathrm{C}\right)$ & 79 & 140 & 135.78 & 133.34 & 130 & 124.56 & 120 \\
Pour point $\left({ }^{\circ} \mathrm{C}\right)$ & 7 & 1.2 & 1.5 & 1.8 & 2 & 2.5 & 3 \\
Lower Heating Value $(\mathrm{MJ} / \mathrm{kg})$ & 44.2 & 38.753 & 42.209 & 41.987 & 41.632 & 40.098 & 39.456 \\
\hline
\end{tabular}

Table 5. FAME ( $w / w \%)$ biodiesel produced from WCO.

\begin{tabular}{ccc}
\hline Common Name & Structure & WCOME \\
\hline Methyl Palmitate & C16:0 & 6 \\
Methyl Palmitoleate & $\mathrm{C} 16: 1$ & 0.6 \\
Methyl Eicosenoate & $\mathrm{C} 20: 1$ & 0.8 \\
Methyl Behenate & $\mathrm{C} 22: 0$ & 0.9 \\
Methyl Arachidate & $\mathrm{C} 20: 0$ & 0.9 \\
Methyl Stearate & $\mathrm{C} 18: 0$ & 0.8 \\
Methyl Oleate & $\mathrm{C} 18: 1$ & 54.0 \\
Methyl Linoleate & $\mathrm{C} 18: 2$ & 25.7 \\
Methyl Erucate & $\mathrm{C} 22: 1$ & 2.2 \\
Methyl Linolenate & $\mathrm{C} 18: 3$ & 8.1 \\
\hline
\end{tabular}

\subsection{Model Fitting and ANOVA}

Table 6 represents ANOVA parameters for the quadratic polynomial model. These predicted values are obtained from model fitting techniques using Design-Expert software 8.0.6. There are various data fitting models that include linear, two factorial, cubic and quadratic. The quadratic polynomial model was used for data fitting, and the equation for this model is shown below.

$$
\begin{gathered}
\text { Yield }(\%)=+84.33-0.16 \mathrm{X}_{1}-5.34 \mathrm{X}_{2}-7.59 \mathrm{X}_{3}+3.44 \mathrm{X}_{4}+0.97 \mathrm{X}_{5}+4.00 \mathrm{X}_{1} \mathrm{X}_{2}+1.75 \mathrm{X}_{1} \mathrm{X}_{3} \\
+5.50 \mathrm{X}_{1} \mathrm{X}_{4}+2.13 \mathrm{X}_{1} \mathrm{X}_{5}+6.38 \mathrm{X}_{2} \mathrm{X}_{3}-0.38 \mathrm{X}_{2} \mathrm{X}_{4}-0.13 \mathrm{X}_{2} \mathrm{X}_{5}-0.38 \mathrm{X}_{3} \mathrm{X}_{4}+1.62 \mathrm{X}_{3} \mathrm{X}_{5}+ \\
0.50 \mathrm{X}_{4} \mathrm{X}_{5}-2.56 \mathrm{X}_{1}^{2}-2.06 \mathrm{X}_{2}^{2}-6.81 \mathrm{X}_{3}^{2}-1.19 \mathrm{X}_{4}^{2}-2.90 \mathrm{X}_{5}^{2}
\end{gathered}
$$


where $X_{1}$ is temperature, $X_{2}$ is catalyst concentration, $X_{3}$ is methanol to oil ratio, and $X_{4}$ is stirring speed, $X_{5}$ is reaction time. The model F-value of 2.70 means that the model is significant. A model F-value this large could only occur at $1.00 \%$ due to noise. "Prob $>F$ " values less than 0.0500 show significant model terms. Values over 0.1000 are not significant in terms of the model. The experimental matrix developed by Design-Expert software which consists of CCD arrangements and responses has been shown in Table 7.

Table 6. ANOVA for the quadratic polynomial model.

\begin{tabular}{|c|c|c|c|c|c|}
\hline Source & Sum of Squares & Degree of Freedom & Mean Square & F Value & Prob $>$ F \\
\hline Model & 2401.89 & 20 & 120.09 & 2.7 & $0.0100^{a}$ \\
\hline A-Temperature & 0.39 & 1 & 0.39 & $8.78 \times 10^{-3}$ & $0.9261^{b}$ \\
\hline $\begin{array}{l}\text { B-Catalyst } \\
\text { concentration }\end{array}$ & 456.89 & 1 & 456.89 & 10.27 & $0.0037^{\mathrm{a}}$ \\
\hline C-Methanol/Oil & 922.64 & 1 & 922.64 & 20.74 & $0.0001^{\mathrm{a}}$ \\
\hline $\begin{array}{l}\text { D-stirring } \\
\text { speed }\end{array}$ & 189.06 & 1 & 189.06 & 4.25 & $0.0498^{a}$ \\
\hline E-Time & 15.02 & 1 & 15.02 & 0.34 & $0.5664^{b}$ \\
\hline $\mathrm{AB}$ & 64 & 1 & 64 & 1.44 & $0.2416^{b}$ \\
\hline $\mathrm{AC}$ & 12.25 & 1 & 12.25 & 0.28 & $0.6043^{b}$ \\
\hline $\mathrm{AD}$ & 121 & 1 & 121 & 2.72 & $0.1116^{b}$ \\
\hline $\mathrm{AE}$ & 18.06 & 1 & 18.06 & 0.41 & $0.5297^{b}$ \\
\hline $\mathrm{BC}$ & 162.56 & 1 & 162.56 & 3.66 & $0.0674^{\mathrm{a}}$ \\
\hline $\mathrm{BD}$ & 0.56 & 1 & 0.56 & 0.013 & $0.9114^{b}$ \\
\hline $\mathrm{BE}$ & 0.063 & 1 & 0.063 & $1.41 \times 10^{-3}$ & $0.9704^{b}$ \\
\hline $\mathrm{CD}$ & 0.56 & 1 & 0.56 & 0.013 & $0.9114^{b}$ \\
\hline $\mathrm{CE}$ & 10.56 & 1 & 10.56 & 0.24 & $0.6303^{b}$ \\
\hline $\mathrm{DE}$ & 1 & 1 & 1 & 0.022 & $0.8820^{b}$ \\
\hline $\mathrm{A} 2$ & 57.31 & 1 & 57.31 & 1.29 & $0.2671^{b}$ \\
\hline B2 & 37.13 & 1 & 37.13 & 0.83 & $0.3696^{b}$ \\
\hline $\mathrm{C} 2$ & 405.03 & 1 & 405.03 & 9.11 & $0.0058^{a}$ \\
\hline D2 & 12.31 & 1 & 12.31 & 0.28 & $0.6035^{b}$ \\
\hline E2 & 73.19 & 1 & 73.19 & 1.65 & $0.2113^{b}$ \\
\hline Residual & 1111.92 & 25 & 44.48 & & \\
\hline Lack of Fit & 981.58 & 20 & 49.08 & 1.88 & $0.2498^{b}$ \\
\hline Pure Error & 130.33 & 5 & 26.07 & & \\
\hline Cor Total & 3513.8 & 45 & & & \\
\hline
\end{tabular}

Table 7. CCD arrangements and responses.

\begin{tabular}{ccccccc}
\hline Trail No & Temperature (A) & $\begin{array}{c}\text { Catalyst } \\
\text { Concertation (B) }\end{array}$ & $\begin{array}{c}\text { Methanol-Oil } \\
\text { Ratio (C) }\end{array}$ & $\begin{array}{c}\text { Stirring } \\
\text { Speed (D) }\end{array}$ & Time (E) & Biodiesel Yield \\
\hline 1 & 65 & 1.75 & 8.5 & 600 & 2 & 76 \\
2 & 57.5 & 1 & 5 & 600 & 3 & 84 \\
3 & 65 & 1 & 8.5 & 600 & 3 & 77 \\
4 & 57.5 & 1 & 5 & 800 & 2 & 90 \\
5 & 57.5 & 0.25 & 12 & 600 & 2 & 63.5 \\
6 & 57.5 & 1 & 8.5 & 800 & 3 & 85 \\
7 & 57.5 & 1 & 12 & 800 & 2 & 76 \\
8 & 65 & 1 & 5 & 600 & 2 & 86.5 \\
9 & 65 & 1 & 12 & 600 & 2 & 77.5 \\
10 & 57.5 & 1 & 8.5 & 600 & 2 & 84.5 \\
11 & 57.5 & 1 & 12 & 600 & 3 & 65.5 \\
12 & 50 & 1 & 8.5 & 800 & 2 & 84 \\
13 & 57.5 & 1 & 8.5 & 600 & 2 & 91.5 \\
14 & 57.5 & 1 & 5 & 400 & 2 & 75 \\
15 & 57.5 & 1 & 5 & 600 & 1 & 86.5 \\
16 & 57.5 & 1 & 8.5 & 800 & 1 & 74 \\
17 & 57.5 & 1 & 8.5 & 600 & 2 & 75.5 \\
18 & 57.5 & 0.25 & 8.5 & 600 & 1 & 91 \\
\hline
\end{tabular}


Table 7. Cont.

\begin{tabular}{ccccccc}
\hline Trail No & Temperature (A) & $\begin{array}{c}\text { Catalyst } \\
\text { Concertation (B) }\end{array}$ & $\begin{array}{c}\text { Methanol-Oil } \\
\text { Ratio (C) }\end{array}$ & $\begin{array}{c}\text { Stirring } \\
\text { Speed (D) }\end{array}$ & Time (E) & Biodiesel Yield \\
\hline 19 & 65 & 1 & 8.5 & 800 & 2 & 92.5 \\
20 & 50 & 1 & 8.5 & 600 & 3 & 76 \\
21 & 57.5 & 0.25 & 5 & 600 & 2 & 89.5 \\
22 & 57.5 & 1.75 & 12 & 600 & 2 & 72.5 \\
23 & 65 & 1 & 8.5 & 400 & 2 & 71 \\
24 & 57.5 & 1 & 12 & 600 & 1 & 61.5 \\
25 & 57.5 & 1.75 & 8.5 & 800 & 2 & 71 \\
26 & 50 & 1 & 12 & 600 & 2 & 63 \\
27 & 57.5 & 0.25 & 8.5 & 600 & 3 & 93 \\
28 & 50 & 1 & 8.5 & 600 & 1 & 85 \\
29 & 57.5 & 1 & 8.5 & 400 & 1 & 70 \\
30 & 57.5 & 1 & 8.5 & 400 & 3 & 79 \\
31 & 57.5 & 0.25 & 8.5 & 400 & 2 & 93 \\
32 & 65 & 1 & 8.5 & 600 & 1 & 77.5 \\
33 & 57.5 & 1.75 & 8.5 & 600 & 1 & 73 \\
34 & 57.5 & 1 & 8.5 & 600 & 2 & 85 \\
35 & 57.5 & 1 & 8.5 & 600 & 2 & 85 \\
36 & 57.5 & 1.75 & 8.5 & 400 & 2 & 74 \\
37 & 57.5 & 1.75 & 8.5 & 600 & 3 & 74.5 \\
38 & 57.5 & 1 & 12 & 400 & 2 & 62.5 \\
39 & 57.5 & 0.25 & 8.5 & 800 & 2 & 91.5 \\
40 & 50 & 0.25 & 8.5 & 600 & 2 & 83.5 \\
41 & 50 & 1 & 8.5 & 400 & 2 & 84.5 \\
42 & 50 & 1.75 & 8.5 & 600 & 2 & 74.5 \\
43 & 57.5 & 1.75 & 5 & 600 & 2 & 73 \\
44 & 65 & 1 & 8.5 & 600 & 2 & 69 \\
45 & 57.5 & 1 & 8.5 & 600 & 2 & 84.5 \\
46 & 50 & & 5 & 600 & 2 & 79 \\
\hline
\end{tabular}

\subsection{Effect of Operating Parameters}

This section explains the effects of temperature, catalyst concentration, methanol to oil ratio, reaction stirring speed and reaction time on the biodiesel yield. Figure 2a presents experimentally obtained RSM plot to investigate the effect of catalyst concentration, methanol to oil ratio, stirring speed, reaction time, at a constant temperature range. The amount of WCO sample was $20 \mathrm{~g}$, and the operating temperature ranged between $50{ }^{\circ} \mathrm{C}$ to $65^{\circ} \mathrm{C}$. The catalyst concentration was varied between $0.25 \mathrm{w} / \mathrm{w}$ to $1.75 \mathrm{w} / \mathrm{w}$. As shown in Figure 2a, biodiesel yield increased from $50^{\circ} \mathrm{C}$ to $57.50^{\circ} \mathrm{C}$ and decreased afterwards. The yield decreased by increasing catalyst concentration from $0.25 w / w$ to $1.75 w / w$. Figure $2 \mathrm{~b}$ illustrates a relation between temperature, methanol to oil ratio and percentage yield of biodiesel at a constant catalyst concentration of $1 w / w$, constant stirring speed of $600 \mathrm{rpm}$ and constant reaction time of $2 \mathrm{~h}$. The biodiesel yield was increased from 5:1 to 8:1 and decreased afterwards. The maximum yield of $93 \%$ was obtained at 8.50:1 methanol to oil ratio. Figure 2c illustrates a relationship between temperature, stirring speed and yield. Biodiesel yield was optimised at stirring speeds between 560 to $640 \mathrm{rpm}$, and it decreased at higher stirring speeds. Figure $2 \mathrm{~d}$ illustrates a relationship between temperature, reaction time and percentage yield of biodiesel at a constant catalyst concentration of $1 w / w$, methanol to oil ratio of 8.50:1 and a constant stirring speed of $600 \mathrm{rpm}$. A slight increase in yield was observed by increasing reaction time from $1 \mathrm{~h}$ to $2 \mathrm{~h}$. Biodiesel yield was enhanced when the temperature increased to $57.50{ }^{\circ} \mathrm{C}$ and then decreased by increasing the temperature further. The above-stated trends are consistent with the results already reported in the literature $[43,44]$.

Figure 3a illustrates response surface plots as a function of catalyst concentration, methanol to oil ratio and percentage yield of biodiesel at a constant temperature of $57.50^{\circ} \mathrm{C}$, the rotational speed of $600 \mathrm{rpm}$ and constant reaction time of $2 \mathrm{~h}$. Minimum biodiesel yield was observed at 12:1 methanol to oil ratio with catalyst concentration of $1.75 w / w$. Maximum biodiesel yield (93\%) was observed at $8.50: 1$ methanol to oil ratio and $0.25 w / w$ catalyst concentration. Figure $3 \mathrm{~b}$ shows that, by changing 
rotational speed from $400 \mathrm{rpm}$ to $800 \mathrm{rpm}$, there is a sharp increase in percentage yield from $80 \%$ to $90 \%$ at a catalyst concentration of $0.25 \mathrm{w} / \mathrm{w}$. Figure $3 \mathrm{c}$ illustrates that both reaction time and catalyst concentration affect the percentage yield. By increasing the reaction time up to a certain limit, and by decreasing catalyst concentration, the percentage yield of biodiesel increased.

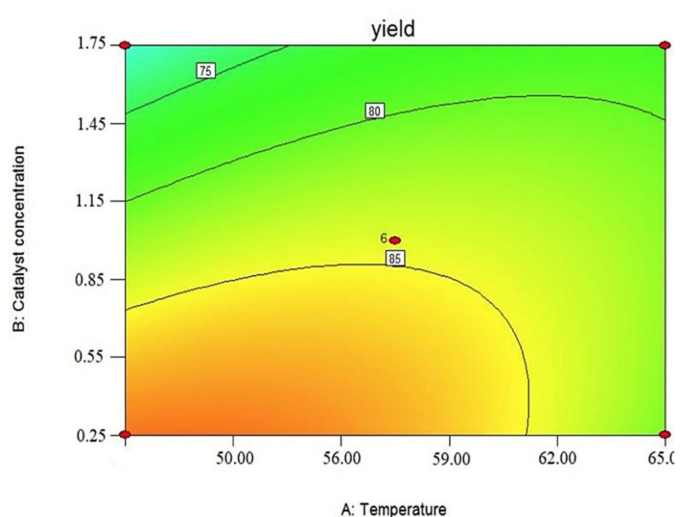

(a)

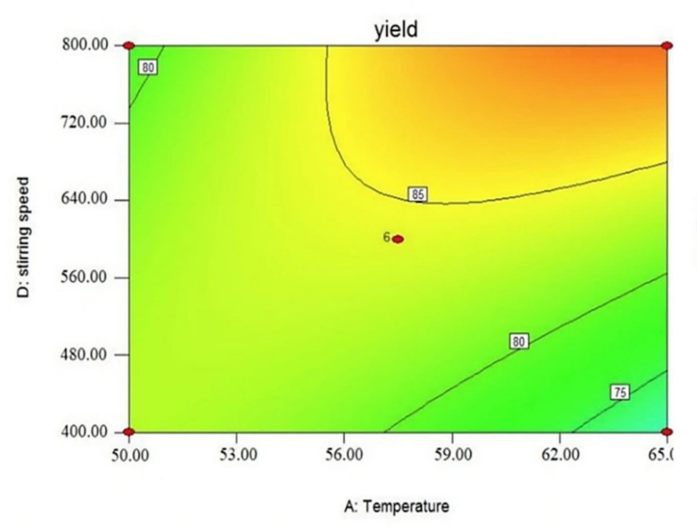

(c)

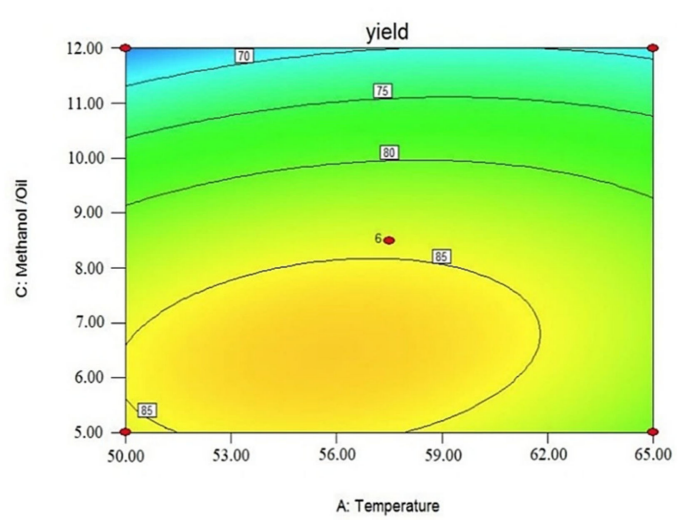

(b)

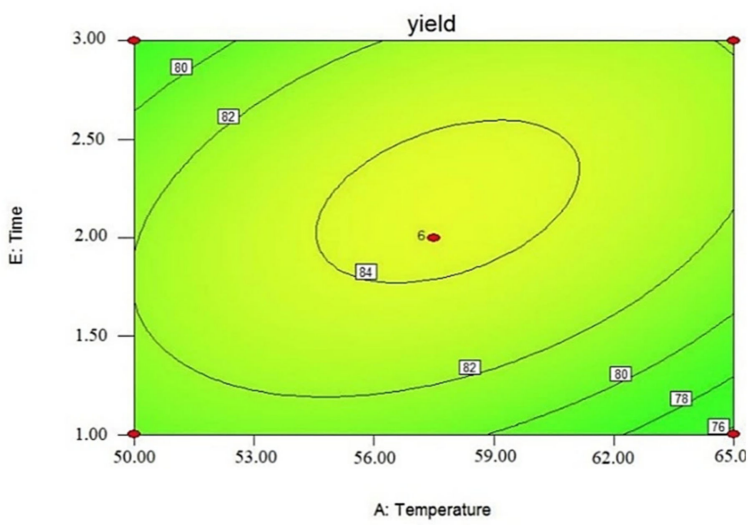

(d)

Figure 2. Experimentally obtained RSM plot to investigate the effect of (a) catalyst concentration, (b) methanol to oil ratio (c) stirring speed (d) reaction time, at a constant range of temperature.

Figure 4a illustrates response surface plots as a function of methanol to oil ratio, stirring speed and percentage yield of biodiesel at a constant temperature, catalyst concentration and reaction time that are $57.50{ }^{\circ} \mathrm{C}, 1 \mathrm{w} / \mathrm{w}$ and $2 \mathrm{~h}$ respectively. Percentage yield sharply increased from $70 \%$ to $90 \%$ by increasing the stirring speed from $400 \mathrm{rpm}$ to $800 \mathrm{rpm}$ with methanol to oil ratio 8.50:1. As shown in Figure $4 \mathrm{~b}$, the optimum yield of biodiesel was observed at 7:1 to 8:1 methanol to oil ratio. Reaction time also affects the yield. Ghadge et al. [45] also reported the use of the same methanol to oil ratio in his investigation. Figure 5, illustrates response surface plots as a function of stirring speed, reaction time and percentage yield of biodiesel at a constant temperature, catalyst concentration, and methanol to oil ratio that are $57.50{ }^{\circ} \mathrm{C}, 1 \mathrm{w} / \mathrm{w}$ and $8.50: 1$ respectively. The graph shows a steady increase in yield by increasing rotational speed and reaction time. 


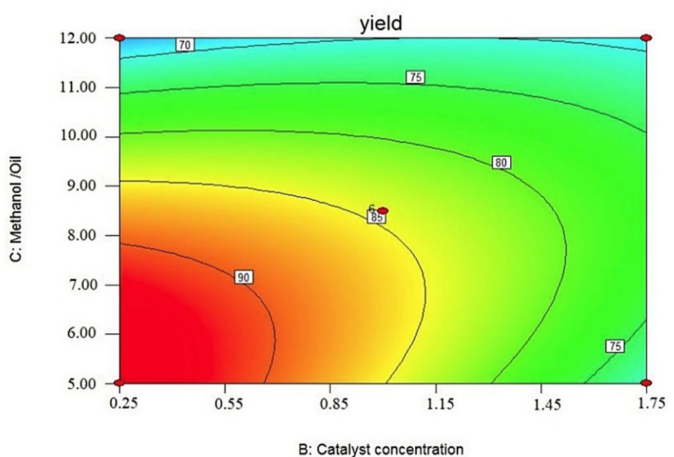

(a)

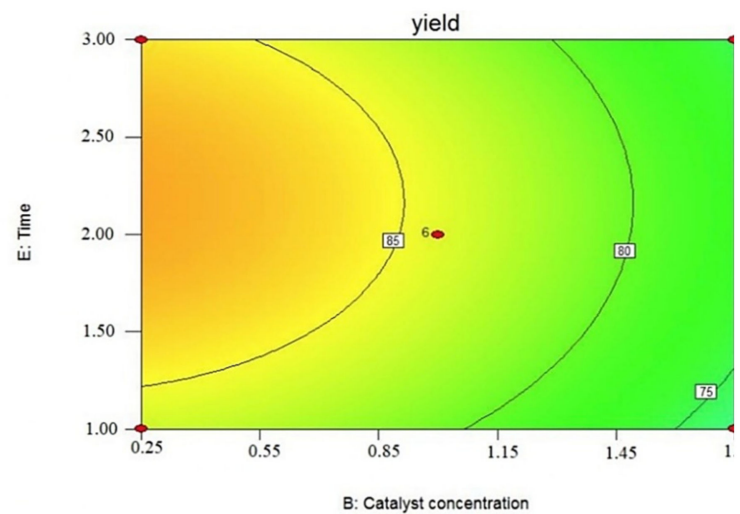

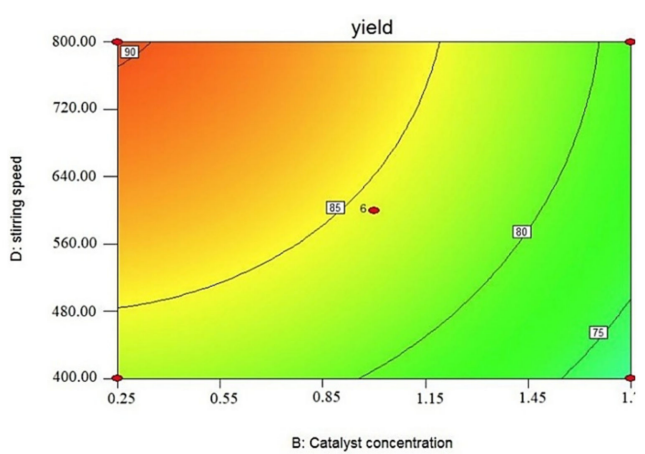

(b)

(c)

Figure 3. Experimentally obtained RSM plot to investigate the effect of (a) methanol to oil ratio, (b) stirring speed and (c) reaction time, at a constant range of catalyst concentration.

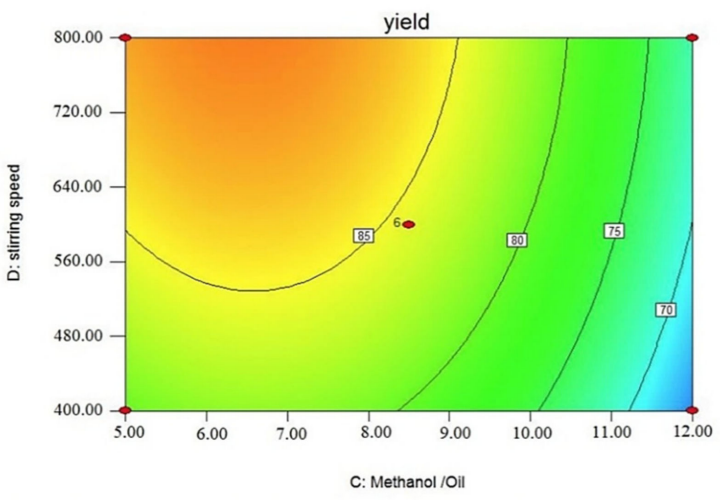

(a)

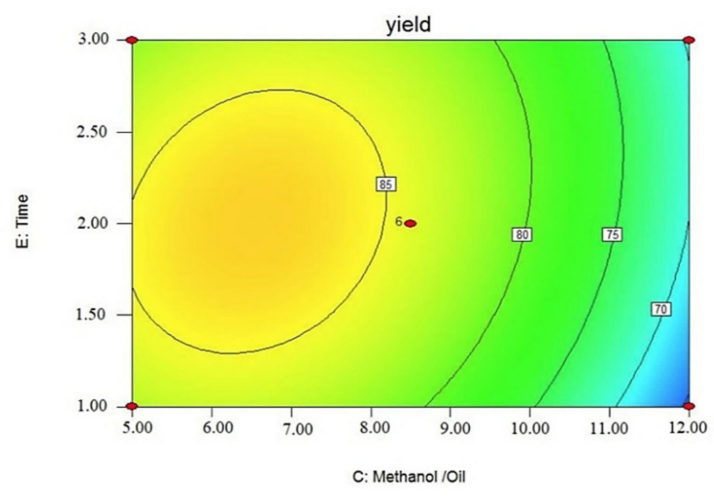

(b)

Figure 4. Experimentally obtained RSM plot to investigate the effect of (a) stirring speed, (b) reaction time, at a constant range of methanol to oil ratio. 


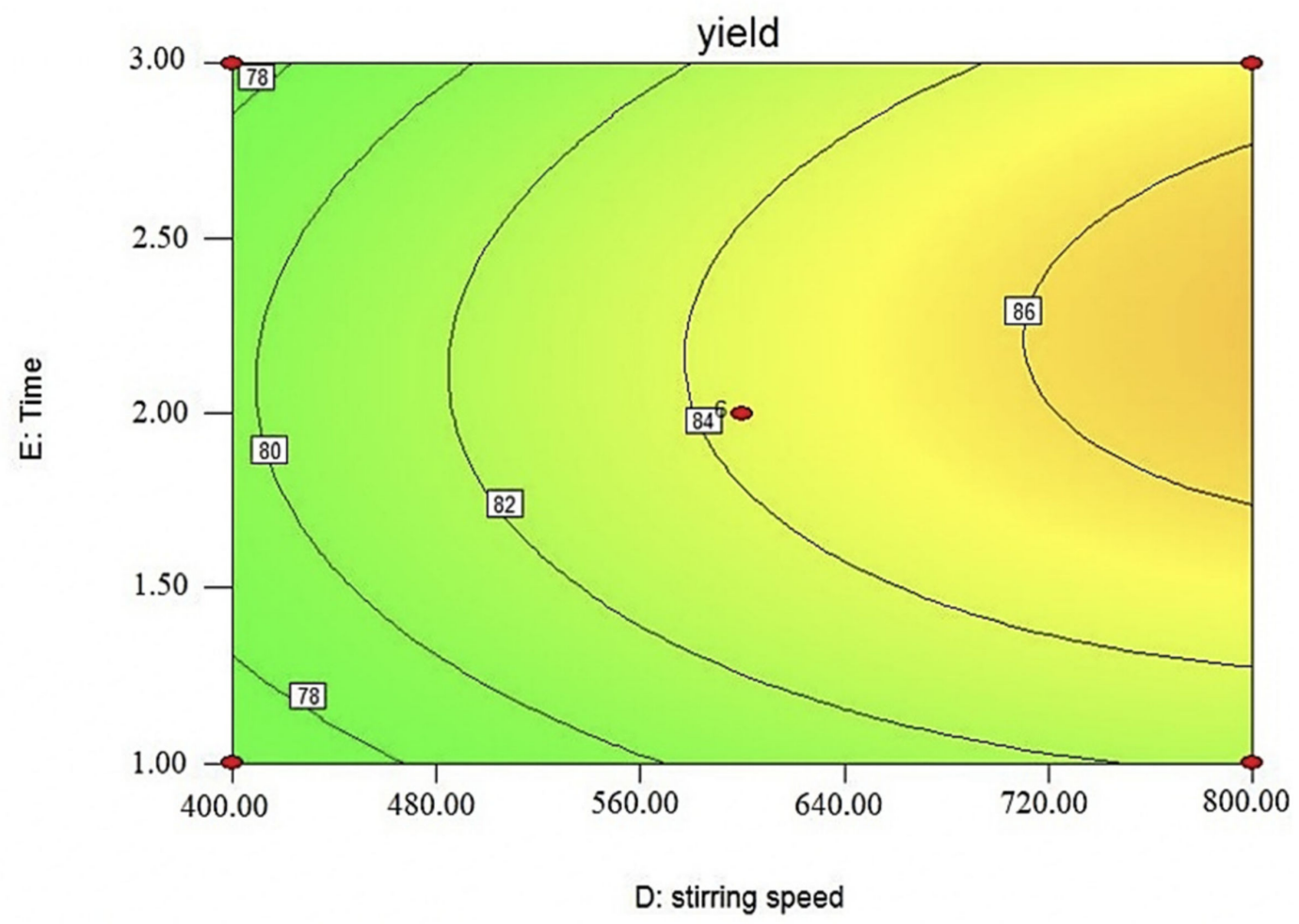

Figure 5. Experimentally obtained RSM plot to investigate the effect of reaction time at a constant range of stirring speed.

\subsection{Performance Characteristics}

\subsubsection{Brake Torque and Brake Power}

Figure $6 \mathrm{a}, \mathrm{b}$ shows the variation of brake torque and brake power with engine speed at full load condition for biodiesel blends and HSD. The trends for biodiesel blends were found to be similar to the HSD. Initially, the brake torque for HSD and biodiesel blends increases with the increase in engine speed, and it reaches a maximum value and then starts to decrease afterwards. This trend can be attributed to: firstly, the volumetric efficiency of the engine which decreases with increase in engine speed and secondly, the increase in frictional losses at higher engine speeds which results in the reduction of the brake torque. The maximum values of engine torque for both HSD and biodiesel blends were found at $3000 \mathrm{rpm}$. Biodiesel blends exhibited slightly lower brake torque than that of HSD. This can be attributed to the relatively low LHV and higher kinematic viscosity of biodiesel blends. Higher kinematic viscosity results in a greater delay in the start of injection, which also leads to poorer fuel atomisation [46]. The average torque reduction for biodiesel blends compared to HSD at $3000 \mathrm{rpm}$ was found to be $1.45 \%$ for B10, $2 \%$ for B20, 2.2\% for B30, 3.09\% for B 40 , and 3.5\% for B50. Brake power is derived from brake torque by multiplying with the angular speed. From Figure $6 b$, the highest power was observed at $3500 \mathrm{rpm}$. Again, the highest power was shown by HSD followed by B10, B20, B30, B40 and B50, respectively. Rizwanul Fattah et al. [46] studied the engine performance, and emission characteristics of Malaysian Alexandrian Laurel oil-based biodiesel (ALB) blend with diesel. They also reported a slight reduction in maximum brake powers for ALB10 and ALB20 compared to that of diesel fuel. The power outputs were $48.5 \mathrm{~kW}, 48.3 \mathrm{~kW}$, and $48.2 \mathrm{~kW}$, for diesel, ALB10, and ALB20, respectively. They attributed this reduction to the lower LHV and higher viscosity of blends, both of which result in poor fuel atomisation compared to that of diesel fuel. 


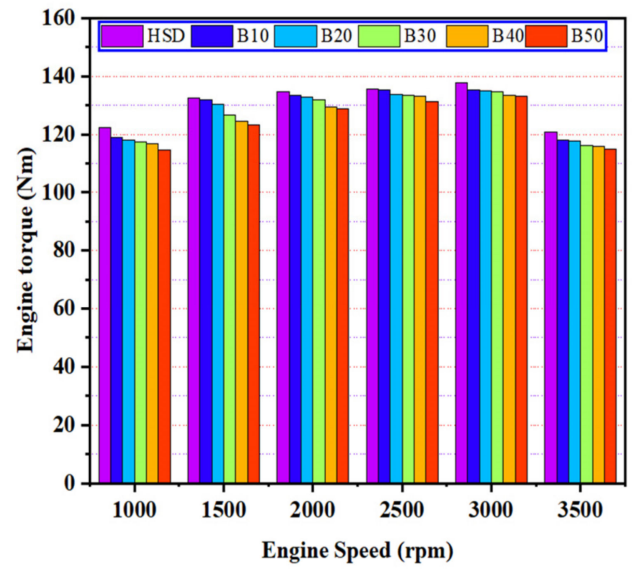

(a)

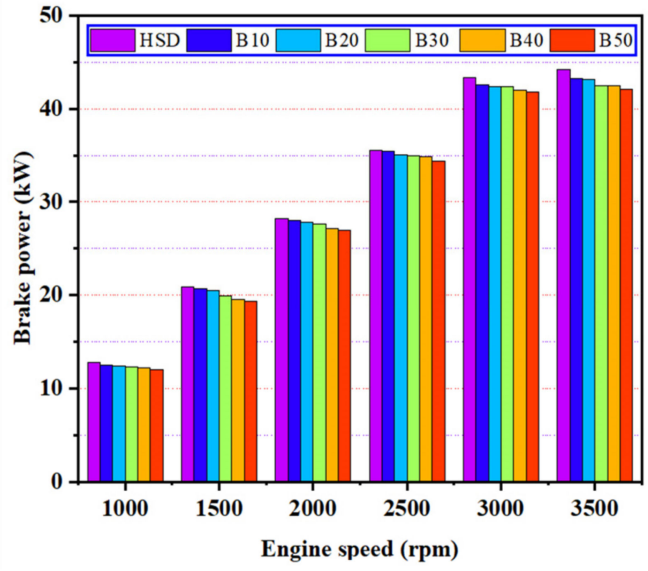

(b)

Figure 6. Effect of different fuels on (a) BT and (b) BP of the engine at different speeds.

\subsubsection{Brake Specific Fuel Consumption and Brake Thermal Efficiency}

Figure 7a presents the variation in BSFC for biodiesel blends and HSD as a function of engine speed. Biodiesel blends have lower LHV and higher densities compared to that of HSD, resulting in higher fuel consumption for biodiesel blends. It is evident for the figure that, BSFC first decreased to the lowest at $2000 \mathrm{rpm}$, and then increased with increase in speed. The average increase in BSFC for biodiesel blends as compared to HSD at $3500 \mathrm{rpm}$ is found as $1.61 \%$ for $\mathrm{B} 10,5.73 \%$ for $\mathrm{B} 20,8.8 \%$ for $\mathrm{B} 30,12.76 \%$ for $\mathrm{B} 40$, and $18 \%$ for B50. The increase in BSFC for biodiesel blends was due to volumetric effect of the constant fuel injection rate together with the higher kinematic viscosity and lower LHV of biodiesel and its blends, and this became more pronounced in higher biodiesel blends such as B50. Palash et al. [47] also reported a similar finding for Aphanamixis polystachya biodiesel (APME) blends with the average BSFC values for diesel, APME5, and APME10 of $352.96 \mathrm{~g} / \mathrm{kWh}, 356.05 \mathrm{~g} / \mathrm{kWh}$, and $359.29 \mathrm{~g} / \mathrm{kWh}$, respectively. Figure $7 \mathrm{~b}$ represents variation in BTE as a function of engine speed at full load conditions. Thermal efficiency varies inversely with the product of BSFC and LHV of the fuel [46]. The highest BTE for all fuels were observed at $3000 \mathrm{rpm}$ at full load condition. The BTE values for HSD, B10, B20, B30, B40 and B50 are $34.97 \%, 32.78 \%, 33.36 \%, 33.76 \%, 34.15 \%$, and $32.11 \%$, respectively.

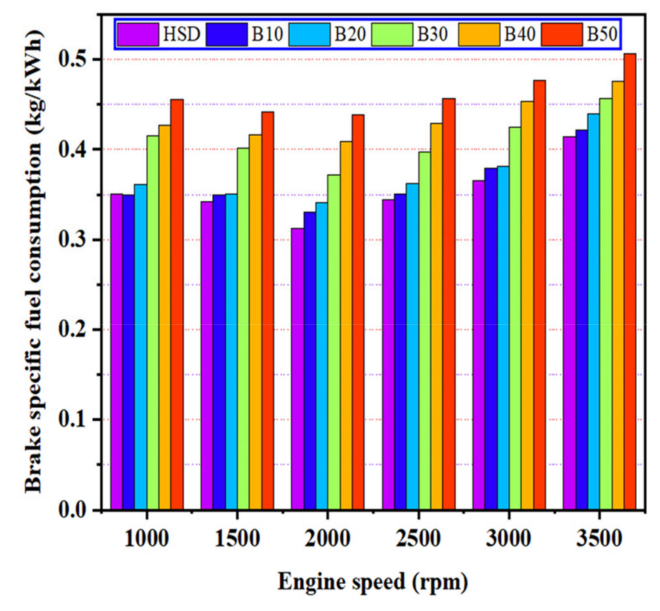

(a)

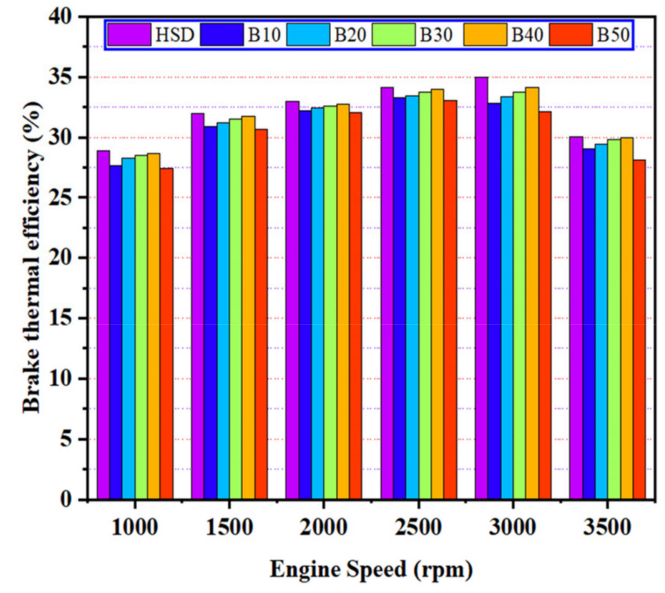

(b)

Figure 7. Effect of different fuels on (a) BSFC and (b) BTE of the engine at different speeds. 


\section{Conclusions}

Biodiesel yield was optimised at optimum operating conditions. FFAs of WCO were reduced by acid treatment. Among mineral acids, $\mathrm{H}_{2} \mathrm{SO}_{4}$ was found to be more effective. It reduces the FFAs value of $91.36 \%$. Transesterification of WCO with methanol was found to be very effective. A biodiesel yield of $93 \%$ was obtained with a $57.50{ }^{\circ} \mathrm{C}$ reaction temperature, $0.25 \%$ catalyst concentration, 8.50:1 methanol to oil ratio, $600 \mathrm{rpm}$ stirring speed, and $3 \mathrm{~h}$ reaction time. Various physiochemical properties justify the quality of biodiesel. Oleic acid (C18:1), linoleic acid (C18:2), $\alpha$-linoleic acid (C18:3), and palmitic acid (C16:0) were the major constituents of biodiesel. Performance characteristics of a diesel engine using diesel fuel and biodiesel blends B10, B20, B30, B40, and B50 were tested and compared. Engine performance in terms of brake torque, brake power, BSFC, and BTE was determined. The average torque reduction for biodiesel blends compared to HSD at $3000 \mathrm{rpm}$ were found to be $1.45 \%, 2 \%, 2.2 \%, 3.09 \%$, and 3.5\% for B10, B20, B30, B40, and B50, respectively. The average increase in BSFC for biodiesel blends compared to HSD at $3500 \mathrm{rpm}$ were found to be $1.61 \%, 5.73 \%, 8.8 \%, 12.76 \%$, and $18 \%$ for B10, B20, B30, B40, and B50, respectively. Pakistan is spending a huge amount of money in importing HSD to fulfil their energy requirements. The government is looking for alternative fuels that have the potential to reduce the consumption of HSD. At present, the most suitable alternative fuel is biodiesel produced from WCO. The conversion of WCO into biodiesel not only reduces the import of HSD, but also reduces environmental concerns.

Author Contributions: Conceptualisation, L.R., Z.A., and S.I.; methodology, M.E.M.S.; software, M.E.M.S.; validation, M.M.A., H.M.K., and T.A.; formal analysis, M.M.A.; investigation N.S.; resources, M.M.A. and M.E.M.S.; data curation, M.E.M.S.; writing—original draft preparation, M.F.; writing—review and editing, S.M.A.R., I.M.R.F., and M.M.A.; visualisation, M.A.; supervision, L.R.; project administration, N.S.; funding acquisition, M.M.A. All authors have read and agreed to the published version of the manuscript.

Funding: This research received no external funding.

Acknowledgments: The authors would like to thank to the Pakistan Council of Scientific and Industrial Research (PCSIR) for their services regarding biodiesel characterisation. Authors would also like to acknowledge 'research development fund' of School of Information, Systems and Modelling, Faculty of Engineering and Information Technology, University of Technology Sydney, Australia.

Conflicts of Interest: The authors declare no conflict of interest.

\section{Nomenclature}

$\begin{array}{ll}\text { ANOVA } & \text { Analysis of Variance } \\ \text { ANFIS } & \text { Adaptive neuro-fuzzy inference system } \\ \text { AV } & \text { Acid value } \\ \text { BSFC } & \text { Brake specific fuel consumption } \\ \text { BP } & \text { Brake power } \\ \text { BTE } & \text { Brake thermal efficiency } \\ \text { BT } & \text { Brake torque } \\ \text { CCD } & \text { Central Composite Design } \\ \text { CI } & \text { Compression ignition } \\ \text { DI } & \text { Direct injection } \\ \text { FAME } & \text { Fatty acid methyl ester } \\ \text { FFA } & \text { Free fatty acid } \\ \text { GCMS } & \text { Gas chromatography-mass spectroscopy } \\ \text { HSD } & \text { High-speed diesel } \\ \text { HPLC } & \text { High-Performance Liquid Chromatography } \\ \text { LHV } & \text { Lower heating value } \\ \text { NMR } & \text { Nuclear magnetic resonance } \\ \text { RSM } & \text { Response surface methodology } \\ \text { WCO } & \text { Waste cooking oil }\end{array}$




\section{References}

1. Soudagar, M.E.M.; Banapurmath, N.R.; Afzal, A.; Hossain, N.; Abbas, M.M.; Haniffa, M.A.C.M.; Naik, B.; Ahmed, W.; Nizamuddin, S.; Mubarak, N.M. Study of diesel engine characteristics by adding nanosized zinc oxide and diethyl ether additives in Mahua biodiesel-diesel fuel blend. Sci. Rep. 2020, 10, 15326. [CrossRef] [PubMed]

2. Hussain, F.; Soudagar, M.E.M.; Afzal, A.; Mujtaba, M.; Fattah, I.M.R.; Naik, B.; Mulla, M.H.; Badruddin, I.A.; Khan, T.M.Y.; Raju, V.D.; et al. Enhancement in Combustion, Performance, and Emission Characteristics of a Diesel Engine Fueled with Ce-ZnO Nanoparticle Additive Added to Soybean Biodiesel Blends. Energies 2020, 13, 4578. [CrossRef]

3. Mujtaba, M.A.; Masjuki, H.H.; Kalam, M.A.; Noor, F.; Farooq, M.; Ong, H.C.; Gul, M.; Soudagar, M.E.M.; Bashir, S.; Fattah, I.M.R.; et al. Effect of Additivized Biodiesel Blends on Diesel Engine Performance, Emission, Tribological Characteristics, and Lubricant Tribology. Energies 2020, 13, 3375. [CrossRef]

4. Baudry, G.; Macharis, C.; Vallée, T. Can microalgae biodiesel contribute to achieve the sustainability objectives in the transport sector in France by 2030? A comparison between first, second and third generation biofuels though a range-based Multi-Actor Multi-Criteria Analysis. Energy 2018, 155, 1032-1046. [CrossRef]

5. Usman, M.; Farooq, M.; Naqvi, M.; Saleem, M.W.; Hussain, J.; Naqvi, S.R.; Jahangir, S.; Jazim Usama, H.M.; Idrees, S.; Anukam, A. Use of gasoline, LPG and LPG-HHO blend in SI engine: A comparative performance for emission control and sustainable environment. Processes 2020, 8, 74. [CrossRef]

6. Masjuki, H.H.; Ruhul, A.M.; Mustafi, N.N.; Kalam, M.A.; Arbab, M.I.; Rizwanul Fattah, I.M. Study of production optimization and effect of hydroxyl gas on a CI engine performance and emission fueled with biodiesel blends. Int. J. Hydrog. Energy 2016, 41, 14519-14528. [CrossRef]

7. Shahir, S.A.; Masjuki, H.H.; Kalam, M.A.; Imran, A.; Rizwanul Fattah, I.M.; Sanjid, A. Feasibility of diesel-biodiesel-ethanol/bioethanol blend as existing CI engine fuel: An assessment of properties, material compatibility, safety and combustion. Renew. Sustain. Energy Rev. 2014, 32, 379-395. [CrossRef]

8. Shuba, E.S.; Kifle, D. Microalgae to biofuels: 'Promising' alternative and renewable energy, review. Renew. Sustain. Energy Rev. 2018, 81, 743-755. [CrossRef]

9. Mahlia, T.M.I.; Syazmi, Z.; Mofijur, M.; Abas, A.E.P.; Bilad, M.R.; Ong, H.C.; Silitonga, A.S. Patent landscape review on biodiesel production: Technology updates. Renew. Sustain. Energy Rev. 2020, 118. [CrossRef]

10. Serin, H.; Yıldizhan, S. Hydrogen addition to tea seed oil biodiesel: Performance and emission characteristics. Int. J. Hydrog. Energy 2018, 43, 18020-18027. [CrossRef]

11. Imran, S.; Korakianitis, T.; Shaukat, R.; Farooq, M.; Condoor, S.; Jayaram, S. Experimentally tested performance and emissions advantages of using natural-gas and hydrogen fuel mixture with diesel and rapeseed methyl ester as pilot fuels. Appl. Energy 2018, 229, 1260-1268. [CrossRef]

12. Imran, S.; Emberson, D.R.; Hussain, A.; Ali, H.; Ihracska, B.; Korakianitis, T. Performance and specific emissions contours throughout the operating range of hydrogen-fueled compression ignition engine with diesel and RME pilot fuels. Alex. Eng. J. 2015, 54, 303-314. [CrossRef]

13. Alagu, K.; Venu, H.; Jayaraman, J.; Raju, V.D.; Subramani, L.; Appavu, P.; Dhanasekar, S. Novel water hyacinth biodiesel as a potential alternative fuel for existing unmodified diesel engine: Performance, combustion and emission characteristics. Energy 2019, 179, 295-305. [CrossRef]

14. Vigneswaran, R.; Annamalai, K.; Dhinesh, B.; Krishnamoorthy, R. Experimental investigation of unmodified diesel engine performance, combustion and emission with multipurpose additive along with water-in-diesel emulsion fuel. Energy Convers. Manag. 2018, 172, 370-380. [CrossRef]

15. Yunus Khan, T.M.; Badruddin, I.A.; Ankalgi, R.F.; Badarudin, A.; Hungund, B.S.; Ankalgi, F.R. Biodiesel Production by Direct Transesterification Process via Sequential Use of Acid-Base Catalysis. Arab. J. Sci. Eng. 2018, 43, 5929-5936. [CrossRef]

16. Fattah, I.M.R.; Ong, H.C.; Mahlia, T.M.I.; Mofijur, M.; Silitonga, A.S.; Rahman, S.M.A.; Ahmad, A. State of the art of catalysts for biodiesel production. Front. Energy Res. 2020. [CrossRef]

17. Vicente, G.; Martínez, M.; Aracil, J. Integrated biodiesel production: A comparison of different homogeneous catalysts systems. Bioresour. Technol. 2004, 92, 297-305. [CrossRef]

18. Mekala, M.; Goli, V.R. Kinetics of esterification of methanol and acetic acid with mineral homogeneous acid catalyst. Chin. J. Chem. Eng. 2015, 23, 100-105. [CrossRef] 
19. Demirbas, A. Biodiesel production from vegetable oils via catalytic and non-catalytic supercritical methanol transesterification methods. Prog. Energy Combust. Sci. 2005, 31, 466-487. [CrossRef]

20. Likozar, B.; Levec, J. Effect of process conditions on equilibrium, reaction kinetics and mass transfer for triglyceride transesterification to biodiesel: Experimental and modeling based on fatty acid composition. Fuel Process. Technol. 2014, 122, 30-41. [CrossRef]

21. Ahmad, T.; Danish, M.; Kale, P.; Geremew, B.; Adeloju, S.B.; Nizami, M.; Ayoub, M. Optimization of process variables for biodiesel production by transesterification of flaxseed oil and produced biodiesel characterizations. Renew. Energy 2019, 139, 1272-1280. [CrossRef]

22. Klofutar, B.; Golob, J.; Likozar, B.; Klofutar, C.; Žagar, E.; Poljanšek, I. The transesterification of rapeseed and waste sunflower oils: Mass-transfer and kinetics in a laboratory batch reactor and in an industrial-scale reactor/separator setup. Bioresour. Technol. 2010, 101, 3333-3344. [CrossRef] [PubMed]

23. Fattah, I.M.R.; Yip, H.L.; Jiang, Z.; Yuen, A.C.Y.; Yang, W.; Medwell, P.R.; Kook, S.; Yeoh, G.H.; Chan, Q.N. Effects of flame-plane wall impingement on diesel combustion and soot processes. Fuel 2019, 255, 115726. [CrossRef]

24. Yip, H.L.; Rizwanul Fattah, I.M.; Yuen, A.C.Y.; Yang, W.; Medwell, P.R.; Kook, S.; Yeoh, G.H.; Chan, Q.N. Flame-Wall Interaction Effects on Diesel Post-injection Combustion and Soot Formation Processes. Energy Fuels 2019, 33, 7759-7769. [CrossRef]

25. Carraretto, C.; Macor, A.; Mirandola, A.; Stoppato, A.; Tonon, S. Biodiesel as alternative fuel: Experimental analysis and energetic evaluations. Energy 2004, 29, 2195-2211. [CrossRef]

26. Rashedul, H.K.; Masjuki, H.H.; Kalam, M.A.; Ashraful, A.M.; Ashrafur Rahman, S.M.; Shahir, S.A. The effect of additives on properties, performance and emission of biodiesel fuelled compression ignition engine. Energy Convers. Manag. 2014, 88, 348-364. [CrossRef]

27. Ashraful, A.M.; Masjuki, H.H.; Kalam, M.A.; Rizwanul Fattah, I.M.; Imtenan, S.; Shahir, S.A.; Mobarak, H.M. Production and comparison of fuel properties, engine performance, and emission characteristics of biodiesel from various non-edible vegetable oils: A review. Energy Convers. Manag. 2014, 80, 202-228. [CrossRef]

28. Nirmala, N.; Dawn, S.S.; Harindra, C. Analysis of performance and emission characteristics of Waste cooking oil and Chlorella variabilis MK039712.1 biodiesel blends in a single cylinder, four strokes diesel engine. Renew. Energy 2020, 147, 284-292. [CrossRef]

29. Akcay, M.; Yilmaz, I.T.; Feyzioglu, A. Effect of hydrogen addition on performance and emission characteristics of a common-rail CI engine fueled with diesel/waste cooking oil biodiesel blends. Energy 2020, 212, 118538. [CrossRef]

30. Can, Ö. Combustion characteristics, performance and exhaust emissions of a diesel engine fueled with a waste cooking oil biodiesel mixture. Energy Convers. Manag. 2014, 87, 676-686. [CrossRef]

31. Nayak, M.G.; Vyas, A.P. Optimization of microwave-assisted biodiesel production from Papaya oil using response surface methodology. Renew. Energy 2019, 138, 18-28. [CrossRef]

32. Mostafaei, M.; Javadikia, H.; Naderloo, L. Modeling the effects of ultrasound power and reactor dimension on the biodiesel production yield: Comparison of prediction abilities between response surface methodology (RSM) and adaptive neuro-fuzzy inference system (ANFIS). Energy 2016, 115, 626-636. [CrossRef]

33. Mubarak, M.; Shaija, A.; Suchithra, T.V. Optimization of lipid extraction from Salvinia molesta for biodiesel production using RSM and its FAME analysis. Environ. Sci. Pollut. Res. 2016, 23, 14047-14055. [CrossRef] [PubMed]

34. Mehta, K.; Divya, N.; Jha, M.K. Application of RSM for Optimizing the Biodiesel Production Catalyzed by Calcium Methoxide. In Sustainable Engineering; Springer: Singapore, 2019; pp. 75-83.

35. Latchubugata, C.S.; Kondapaneni, R.V.; Patluri, K.K.; Virendra, U.; Vedantam, S. Kinetics and optimization studies using Response Surface Methodology in biodiesel production using heterogeneous catalyst. Chem. Eng. Res. Des. 2018, 135, 129-139. [CrossRef]

36. Jamshaid, M.; Masjuki, H.H.; Kalam, M.A.; Zulkifli, N.W.M.; Arslan, A.; Alwi, A.; Khuong, L.S.; Alabdulkarem, A.; Syahir, A.Z. Production optimization and tribological characteristics of cottonseed oil methyl ester. J. Clean. Prod. 2019, 209, 62-73. [CrossRef]

37. Anwar, M.; Rasul, M.G.; Ashwath, N.; Rahman, M.M. Optimisation of Second-Generation Biodiesel Production from Australian Native Stone Fruit Oil Using Response Surface Method. Energies 2018, 11, 2566. [CrossRef] 
38. Veljković, V.B.; Veličković, A.V.; Avramović, J.M.; Stamenković, O.S. Modeling of biodiesel production: Performance comparison of Box-Behnken, face central composite and full factorial design. Chin. J. Chem. Eng. 2019, 27, 1690-1698. [CrossRef]

39. Chai, M.; Tu, Q.; Lu, M.; Yang, Y.J. Esterification pretreatment of free fatty acid in biodiesel production, from laboratory to industry. Fuel Process. Technol. 2014, 125, 106-113. [CrossRef]

40. Fattah, I.M.R.; Masjuki, H.H.; Kalam, M.A.; Wakil, M.A.; Ashraful, A.M.; Shahir, S.A. Experimental investigation of performance and regulated emissions of a diesel engine with Calophyllum inophyllum biodiesel blends accompanied by oxidation inhibitors. Energy Convers. Manag. 2014, 83, 232-240. [CrossRef]

41. Santos, T.; Gomes, J.F.; Puna, J. Liquid-liquid equilibrium for ternary system containing biodiesel, methanol and water. J. Environ. Chem. Eng. 2018, 6, 984-990. [CrossRef]

42. Fattah, I.M.R.; Masjuki, H.H.; Kalam, M.A.; Mofijur, M.; Abedin, M.J. Effect of antioxidant on the performance and emission characteristics of a diesel engine fueled with palm biodiesel blends. Energy Convers. Manag. 2014, 79, 265-272. [CrossRef]

43. Balasubramaniam, B.; Sudalaiyadum Perumal, A.; Jayaraman, J.; Mani, J.; Ramanujam, P. Comparative analysis for the production of fatty acid alkyl esterase using whole cell biocatalyst and purified enzyme from Rhizopus oryzae on waste cooking oil (sunflower oil). Waste Manag. 2012, 32, 1539-1547. [CrossRef] [PubMed]

44. Verma, P.; Sharma, M.P. Comparative analysis of effect of methanol and ethanol on Karanja biodiesel production and its optimisation. Fuel 2016, 180, 164-174. [CrossRef]

45. Ghadge, S.V.; Raheman, H. Biodiesel production from mahua (Madhuca indica) oil having high free fatty acids. Biomass Bioenergy 2005, 28, 601-605. [CrossRef]

46. Fattah, I.M.R.; Kalam, M.A.; Masjuki, H.H.; Wakil, M.A. Biodiesel production, characterization, engine performance, and emission characteristics of Malaysian Alexandrian laurel oil. RSC Adv. 2014, 4, 17787-17796. [CrossRef]

47. Palash, S.M.; Masjuki, H.H.; Kalam, M.A.; Atabani, A.E.; Rizwanul Fattah, I.M.; Sanjid, A. Biodiesel production, characterization, diesel engine performance, and emission characteristics of methyl esters from Aphanamixis polystachya oil of Bangladesh. Energy Convers. Manag. 2015, 91, 149-157. [CrossRef]

Publisher's Note: MDPI stays neutral with regard to jurisdictional claims in published maps and institutional affiliations.

(C) 2020 by the authors. Licensee MDPI, Basel, Switzerland. This article is an open access article distributed under the terms and conditions of the Creative Commons Attribution (CC BY) license (http://creativecommons.org/licenses/by/4.0/). 